\title{
MODEL KOMUNIKASI KAMPANYE PENGGALANGAN DANA OLEH PERUSAHAAN PENYIARAN TELEVISI UNTUK MENDUKUNG KEGIATAN KEMANUSIAAN
}

\author{
Dwi Firmansyah ${ }^{1}$, Eka Perwitasari Fauzi ${ }^{2}$ \\ Fakultas Ilmu Komunikasi, Universitas Mercu Buana \\ e-mail: dfi.firmansyah@gmail.com dan eperwitasari16@gmail.com
}

\begin{abstract}
This research discusses a fundraising campaign by PT Surya Citra Televisi (SCTV) through "Jembatan Asa" program, a humanitarian program to build broken bridges in various regions of Indonesia. The purpose of this research is to know the communication model of humanitarian fundraising campaign of Jembatan Asa Program by SCTV with reference to Nowak and Warneryd campaign model.

The research approach used is qualitative, with the nature of descriptive research. Data collection procedure through advertisement and news documentation and in-depth interviews from key informants: chairman of CSR program "Jembatan Asa", news production manager, news producer and video journalist in SCTV News Division. The results and analysis of data findings show that the campaign is done through advertisements and publications in various internal programs of SCTV, online media www.liputan6.com and social media.

Refers to the elements of the Nowak and Warneryd campaign models; intended effect, competiting communication, communication objects, target populations and receiving groups, channels, messages, communicators, and obtained effects, the researchers found a change in the model used by SCTV in a public fundraising campaign. Among them, prior to conducting the campaign, SCTV produced framing the news of the condition of the affected communities damaged bridges. The contents of campaign messages in the form of donation solicitation adverts, news reports on the construction of bridges and financial reports. The effect of the campaign is the rise of number of public donations, the rise of media reputation, and the government's concern to build another damaged bridge in its territory.
\end{abstract}

Keywords: Communication Model, Campaign, Advertisement, Publication, Fundraising

\begin{abstract}
ABSTRAK
Penelitian ini membahas kampanye penggalangan dana oleh PT Surya Citra Televisi (SCTV) melalui program Jembatan Asa, sebuah program kemanusiaan untuk membangun jembatan rusak di berbagai daerah Indonesia. Tujuan penelitian ini adalah untuk mengetahui model komunikasi kampanye penggalangan dana kemanusiaan Program Jembatan Asa oleh SCTV dengan mengacu pada model kampanye Nowak dan Warneryd.

Pendekatan penelitian yang digunakan adalah kualitatif, dengan sifat penelitian deskriptif. Prosedur pengumpulan data melalui dokumentasi iklan dan berita serta wawancara mendalam dari key informan, yakni Ketua Penyelenggara program CSR Jembatan Asa, Manajer Produksi Berita, Produser Program Liputan 6 dan Video Journalist di Divisi Pemberitaan SCTV. Hasil
\end{abstract}


dan analisis temuan data memperlihatkan bahwa kampanye dilakukan melalui iklan dan publikasi di berbagai program internal SCTV, media online www.liputan6.com dan media sosial.

Mengacu pada elemen model kampanye Nowak dan Warneryd; efek yang diharapkan, persaingan komunikasi, obyek komunikasi, populasi target dan kelompok penerima, saluran, pesan, komunikator, dan efek yang dicapai. Peneliti menemukan perubahan model yang digunakan SCTV dalam kampanye penggalangan dana masyarakat. Diantaranya, sebelum melakukan kampanye, SCTV memproduksi framing berita kondisi masyarakat terdampak jembatan rusak. Isi pesan kampanye berupa iklan ajakan berdonasi, pemberitaan progres pembangunan jembatan dan laporan keuangan. Efek kampanye yang dicapai adalah banyaknya donasi masyarakat, naiknya reputasi media, dan kepedulian pemerintah untuk membangun jembatan rusak lain di wilayahnya.

\section{.Kata kunci: Model Komunikasi, Kampanye, Iklan, Publikasi, Penggalangan dana}

\section{PENDAHULUAN}

\section{Latar Belakang Penelitian}

Dalam menjalankan fungsinya, sebuah perusahaan dituntut untuk tidak hanya berorientasi pada profit semata, namun juga memberikan sumbangsih atau turut berkontribusi pada kehidupan masyaraka. Kontribusi ini merupakan bentuk tanggung jawab perusahaan terhadap kehidupan masyarakat yang lebih baik. Memanfaatkan kelebihannya sebagai media televisi yang memiliki jangkauan nasional di semua kalangan masyarakat, SCTV menjalankan peran sosial menjadi jembatan antara kelompok masyarakat agar tumbuh keterikatan untuk saling peduli dan membantu sesama. SCTV sebagai perusahaan pengelola dana masyarakat (fundraising) menanggung biaya operasional semua kegiatan sebagai salah satu bentuk tanggungjawab sosial perusahaan, dengan cara ini pula, dana masyarakat dapat seoptimal mungkin dipergunakan untuk membantu masyarakat yang membutuhkan. Salah satunya adalah dengan membuat program Jembatan Asa, yaitu sebuah program sosial kerjasama SCTV dengan LSM Relawan Kampung, yang bertujuan membangun jembatan di berbagai daerah yang selama bertahuntahun rusak atau tidak layak digunakan oleh masyarakat. Pembangunan biasanya dilakukan di daerah terpencil yang tidak tersentuh program pemerintah.

Sebagai sebuah perusahaan yang bergerak di bidang pertelevisian, SCTV memiliki keuntungan yaitu bisa mempromosikan dan memublikasikan secara langsung kegiatan CSR dalam tayangan program televisi. Kampanye filantropi dilakukan untuk mengajak masyarakat berpartisipasi menyalurkan 
sumbangan bagi kegiatan kemanusiaan. Sedangkan publikasi bertujuan untuk mendokumentasikan pelaksanaan kegiatan kemanusiaan tersebut sekaligus sebagai laporan pertanggungjawaban penggunaan dana filantropi dari masyarakat.

$$
\text { Program "Jembatan Asa" }
$$
merupakan special programme yang dikelola langsung oleh Manajemen SCTV. Agar lebih fokus, peneliti membatasi permasalahan pada pelaksanaan program "Jembatan Asa" 2015. Peneliti memandang bahwa perlu dikaji lebih mendalam bagaimana model komunikasi kampanye penggalangan dana kegiatan kemanusiaan“Jembatan Asa” oleh SCTV.

\section{Rumusan Masalah}

Berdasarkan latar belakang penelitian yang telah dipaparkan, maka rumusan masalah dalam penelitian ini adalah: "Bagaimanakah model komunikasi kampanye penggalangan dana oleh perusahaan penyiaran televisi untuk mendukung kegiatan kemanusiaan?"

\section{KERANGKA PEMIKIRAN}

\begin{tabular}{|c|}
\hline Penelitian Terdahulu: \\
Sebelumnya telah ada penelitian mengenai publikasi kegiatan CSR perusahaan \\
penyiaran televisi, namun bertujuan untuk menaikkan citra perusahaan di mata audiens. Dengan \\
demikian penelitian untuk mencari model komunikasi dalam kampanye penggalangan dana pada \\
perusahaan penyiaran televisi untuk mendukung kegiatan kemanusiaan yang diajukan ini relevan \\
dan berpotensi untuk melahirkan temuan baru. \\
Tujuan Penelitian ini: \\
Mencari model komunikasi kampanye penggalangan dana perusahaan penyiaran televisi untuk \\
mendukung kegiatan kemanusiaan \\
Kantor SCTV di Jalan Asia Afrika Kav 19A Senayan, Jakarta dan lokasi liputan \\
kegiatan kemanusiaan di Lebak, Banten
\end{tabular}




\begin{tabular}{|c|c|c|}
\hline & (1) & (2) \\
\hline Aktivitas & $\begin{array}{l}\text { Mengidentifikasi proses produksi } \\
\text { iklan dan publikasi berita sebagai } \\
\text { kampanye penggalangan dana untuk } \\
\text { mendukung kegiatan kemanusiaan } \\
\text { pada perusahaan penyiaran televisi } \\
\text { SCTV dengan cara: } \\
\text { 1). Wawancara dengan Ketua } \\
\text { Penyelenggara Program "Jembatan } \\
\text { Asa" SCTV } \\
\text { 2). Wawancara narasumber lain } \\
\text { sesuai arahan ketua Penyelenggara } \\
\text { "Jembatan Asa" SCTV }\end{array}$ & $\begin{array}{l}\text { Menganalisis respons audience } \\
\text { terhadap tayangan publikasi } \\
\text { kampanye penggalangan dana yang } \\
\text { dilakukan SCTV untuk mendukung } \\
\text { kegiatan kemanusiaan, dilakukan } \\
\text { dengan cara: }\end{array}$ \\
\hline Output & $\begin{array}{l}\text { Teridentifikasinya produksi iklan } \\
\text { dan publikasi kampanye } \\
\text { penggalangan dana yang mampu } \\
\text { menggerakkan audience untuk } \\
\text { mendukung kegiatan kemanusiaan }\end{array}$ & $\begin{array}{l}\text { Penemuan Model Komunikasi } \\
\text { Kampanye Penggalangan Dana untuk } \\
\text { mendukung kegiatan kemanusiaan } \\
\text { oleh perusahaan penyiaran televisi. }\end{array}$ \\
\hline \multicolumn{3}{|c|}{$\begin{array}{l}\text { Diperolehnya model komunikasi yang dapat diaplikasikan oleh perusahaan penyiaran televisi } \\
\text { lain untuk mengampanyekan penggalangan dana masyarakat guna mendukung kegiatan } \\
\text { kemanusiaan. }\end{array}$} \\
\hline Semaki & $\begin{array}{l}\text { ginya keterlibatan dan kepedulian mas } \\
\text { nemberikan donasi yang bermanfaat ba }\end{array}$ & $\begin{array}{l}\text { yarakat umtuk saling berbagi dengan } \\
\text { gi kegiatan kemanusiaan. }\end{array}$ \\
\hline
\end{tabular}




\section{TUJUAN PENELITIAN}

Tujuan penelitian adalah sebagai berikut:

- Mengidentifikasi dan menguraikan iklan dan publikasi dalam penggalangan dana oleh perusahaan penyiaran televisi untuk mendukung kegiatan kemanusiaan.

- Membuat model komunikasi dalam kampanye penggalangan dana oleh perusahaan penyiaran televisi untuk mendukung kegiatan kemanusiaan.

\section{TINJAUAN PUSTAKA}

\section{Penggalangan Dana (Fundraising)}

Penggalangan dana (fundraising)
berarti penghimpunan dana atau
penggalangan dana, sedangkan menurut
istilah fundraising merupakan suatu upaya
atau proses kegiatan dalam rangka
menghimpun dana zakat, infaq dan
shodaqoh serta sumber daya lainnya dari
masyarakat baik individu, kelompok,
organisasi dan perusahaan yang akan
disalurkan dan didayagunakan untuk
mustahik (Purwanto, 2009:12). Purwanto
(2009) juga mendefinisikan fundraising
sebagai proses memengaruhi masyarakat
baik perseorangan sebagai individu atau
perwakilan masyarakat maupun lembaga
agar menyalurkan dananya kepada sebuah
organisasi.

Dalam melaksanakan aktivitas penggalangan dana, bagian penghimpunan dapat menyelenggarakan berbagai macam kegiatan. Ragam program kegiatan ini akhirnya dapat ditawarkan sebagai kerja sama program dengan perusahaan dan lembaga yang lain (Sudewo, 2004:189). Inti dari fundraising adalah proses mempengaruhi masyarakat agar mau melakukan amal kebajikan dalam bentuk penyerahan dana atau sumber daya lainnya yang bernilai untuk disampaikan kepada masyarakat yang membutuhkan.

\section{Kampanye}

Kampanye merupakan kegiatan komunikasi yang dilakukan secara terlembaga. Penyelenggara kampanye umumnya bukanlah individu melainkan lembaga atau organisasi yang dapat berasal dari lingkungan pemerintahan, kalangan swasta atau Lembaga Swadaya Masyarakat. Terlepas siapapun penyelenggaranya, kampanye selalu memiliki tujuan yang telah ditetapkan sebelumnya (Venus, 2004:9).

Membicarakan jenis-jenis kampanye pada prinsipnya adalah membicarakan motivasi yang melatarbelakangi diselenggarakannya sebuah program kampanye. Motivasi tersebut pada gilirannya akan menentukan ke arah mana kampanye digerakkan dan apa tujuan yang 
akan dicapai. Jadi secara inheren ada keterkaitan antara motivasi dan tujuan kampanye. Bertolak dariketerkaotan tersebut, Larson (1992) dalam Venus (2004: 10-12) membagi jenis kampanye ke dalam 3 kategori yakni:

1. Product-oriented campaigns, atau kampanye yang berorientasi pada produk yang umumnya terjadi di lingkungan bisnis. Istilah lain untuk kampanye jenis ini adalah commercial campaigns atau corporate campaign. Motivasi yang mendasarinya adalah memperoleh keuntungan finansial. Cara yang ditempuh adalah dengan memperkenalkan produk dan melipatgandakan penjualan sehingga diperoleh keuntungan yang diharapkan. Kampanye Public Relations yang ditujukan untuk membangun citra positif perusahaan di mata publik juga dapat dimasukkan dalam kelompok ini.

2. Candidate-oriented campaigns atau kampanye yang berorientasi pada kandidat umumnya dimotivasi oleh hasrat untuk meraih kekuasaan politik. Karena itu kampanye ini dapat pula disebut sebagai political campaigns. Tujuannya antara lain untuk memenangkan dukungan masyarakat terhadap kandidat-kandidat yang diajukan partai politik agar dapat menduduki jabatan-jabatan politik yang diperebutkan lewat proses pemilihan umum.

3. Ideologically or cause oriented campaigns adalah jenis kampanye yang berorientasi pada tujuan-tujuan yang bersifat khusus dan seringkali berdimensi perubahan sosial. Karena itu kampanye jenis ini dalam istilah Kotler disebut sebagai social change campaigns, yakni kampanye yang ditujukan untuk menangani masalahmasalah sosial melalui perubahan sikap dan perilaku publik yang terkait.

Pesan-pesan kampanye juga terbuka untuk didiskusikan, bahkan gagasangagasan pokok yang melatarbelakangi diselengarakannya kampanye juga terbuka untuk dikritisi. Keterbukaan seperti ini dimungkinkan karena gagasan dan tujuan kampanye pada dasarnya mengandung kebaikan untuk publik. Segala tindakan dalam kegiatan kampanye dilandasi oleh prinsip persuasi, yaitu mengajak dan mendorong publik untuk menerima atau melakukan sesuatu yang dianjurkan atas dasar kesukarelaan. Dengan demikian kampanye pada prinsipnya adalah contoh tindakan persuasi secara nyata. Dalam ungkapan Perloff (1993) dikatakan "Campaigns generally exemplify 
persuasion in action". (Venus, 2004:7)

\section{METODE PENELITIAN}

\author{
Penelitian ini menggunakan \\ paradigma postpositivisme, Guba \\ (1990:20) menjelaskan postpositivisme \\ sebagai berikut "Postpositivism is best \\ characterized as modified version of \\ positivism. Having assesed the damage that \\ positivism has occured, postpositivist \\ struggle to limited that damage as well as to \\ adjust to it. Prediction and control continue \\ to be the aim.".
}

Kutipan itu bermakna bahwa postpositivis mempunyai ciri utama sebagai suatu modifikasi dari positivisme. Melihat banyaknya kekurangan pada positivisme menyebabkan para pendukung postpositivisme berupaya memperkecil kelemahan tersebut dan menyesuaikannya. Prediksi dan kontrol tetap menjadi tujuan dari postpositivisme tersebut.

Salim (2001:40) menjelaskan postpositivisme sebagai berikut: paradigma ini merupakan aliran yang ingin memperbaiki kelemahan-kelemahan positivisme yang hanya mengandalkan kemampuan pengamatan langsung terhadap obyek yang diteliti. Secara ontologis aliran ini bersifat critical realism yang memandang bahwa realitas memang ada dalam kenyataan sesuai dengan hukum alam, tetapi suatu hal, yang mustahil bila suatu realitas dapat dilihat secara benar oleh manusia (peneliti). Oleh karena itu secara metodologi pendekatan eksperimental melalui metode triangulasi yaitu bermacam-macam metode, sumber data, peneliti dan teori.

Secara epistemologis hubungan antara pengamat atau peneliti dengan obyek atau realitas yang diteliti tidaklah bisa dipisahkan, tidak seperti yang diusulkan aliran positivisme. Aliran ini menyatakan suatu hal yang tidak mungkin mencapai atau melihat kebenaran apabila pengamat berdiri di belakang layar tanpa ikut terlibat dengan obyek secara langsung. Oleh karena itu, hubungan antara pengamat dan obyek harus bersifat interaktif, dengan catatan bahwa pengamat harus senetral mungkin, sehingga tingkat subyektivitasnya dapat dikurangi secara minimal (Salim, 2001:40)

$$
\text { Penelitian ini menggunakan }
$$
Pendekatan Deskriptif Kualitatif. Deskriptif kualitatif merupakan metode yang digunakan untuk membedah suatu fenomena di lapangan. Penelitian deskriptif kualitatif adalah metode yang menggambarkan dan menjabarkan temuan di lapangan. Metode deskriptif kualitatif 
hanyalah memaparkan situasi atau peristiwa. Penelitian dengan metode ini tidak mencari atau menjelaskan hubungan, tidak menguji hipotesis atau membuat prediksi. Penelitian deskriptif ditujukan untuk mengumpulkan informasi secara aktual dan terperinci, mengidentifikasikan masalah, membuat perbandingan atau evaluasi, dan menentukan apa yang dilakukan orang lain dalam menghadapi masalah yang sama dan belajar dari pengalaman mereka untuk menetapkan rencana dan keputusan pada waktu yang akan datang.

Peneliti mendeskripsikan secara jelas mengenai kampanye penggalangan dana oleh perusahaan penyiaran televisi untuk mendukung kegiatan kemanusiaan. Sedangkan metode kualitatif digunakan untuk memperoleh sajian data dalam bentuk rinci, mendalam dari para informan. Bodgan dan Tylor dalam Moleong (2001: 21) mendefinisikan bahwa penelitian kualitatif adalah prosedur penelitian yang menghasilkan data deskriptif berupa katakata tertulis atau lisan dari orang-orang dan perilaku yang dapat diamati.

Teknik Pengumpulan data dilakukan dengan wawancara mendalam (in depth interview) kepada key informan dan informan. Metode wawancara mendalam adalah sama seperti metode wawancara lainnya, hanya peran pewawancara, tujuan wawancara, peran informan, dan cara melakukan wawancara mendalam dilakukan berkali-kali dan membutuhkan waktu yang lama bersama informan di lokasi penelitian, hal mana kondisi ini tidak pernah terjadi pada wawancara umumnya (Bungin, 2007: 111).

Peneliti mengumpulkan dokumen yang dapat berupa tulisan, gambar, atau karya-karya monumental dari seseorang (Sugiyono, 2012: 240). Dalam hal ini peneliti menggunakan dokumen berupa video iklan penggalangan dana program "Jembatan Asa" dan video tayangan berita program "Jembatan Asa" di Program Liputan 6 SCTV.

Pemilihan subyek atau key informan dalam penelitian ini menggunakan cara snowbolling sampling dan dilakukan dengan langkah-langkah sebagi berikut: ketika memulai melakukan penelitian dan pengumpulan informasi, peneliti berupaya menemukan siapapun orang pertama yang menerima informasi di lokasi obyek penelitian yang dapat memberi petunjuk tentang siapa yang dapat diwawancarai atau diobservasi dalam rangka memperoleh informasi tentang obyek penelitian. Setelah mewawancarai orang pertama, peneliti meminta key informan menunjuk orang lain 
yang bisa diwawancarai lagi dan begitu seterusnya. Key informan yang pertama kali diwawancarai adalah Ketua penyelenggara program Jembatan Asa Doni Arianto, yang selanjutnya memberi rekomendasi kepada peneliti untuk melakukan wawancara dengan Kepala Produksi Berita Mauluddin Anwar, Manajer Pemberitaan LitaHaryani, dan Video Journalist yang melakukan peliputan Kurnia Supriyatna.

Untuk mengetahui pendapat masyarakat terhadap kampanye penggalangan dana jembatan asa, peneliti juga melakukan Focus Group Discussions (FGD) dengan sejumlah responden. FGD merupakan salah satu metode untuk menggali insight dari audience atas sebuah isu, dalam hal ini publikasi kampanye penggalangan dana di media televisi. Dalam satu kelompok FGD biasanya terdiri dari 8 - 10 orang yang dipandu oleh 1 orang moderator untuk memimpin diskusi mengenai suatu isu. Pada penelitian ini FGD digunakan untuk menganalisis respon audience terhadap tayangan publikasi kampanye penggalangan dana yang dilakukan oleh SCTV.

\section{HASIL PENELITIAN}

Program kemanusiaan "Jembatan Asa" awalnya merupakan kegiatan sosial dalam rangka memperingati ulang tahun SCTV yang ke-25 pada 2015. SCTV melakukan sebuah gerakan kemanusiaan yang merupakan bentuk kepedulian sosial terhadap masyarakat yang mengalami kesulitan. Program kemanusiaan ini dilakukan dengan membangun atau memperbaiki jembatan-jembatan rusak yang ada di Indonesia. Program yang diberi nama "Jembatan Asa SCTV" ini mulai dilakukan April sampai Agustus 2015.

Menurut Doni Arianto, Manajer Divisi Programing SCTV yang ditunjuk sebagai ketua penyelenggara program CSR "Jembatan Asa". Ide awal program ini berasal dari keprihatinan manajemen dan pemirsa setia SCTV terkait banyaknya jembatan di berbagai wilayah terpencil Indonesia yang sudah rusak dan tidak tersentuh pembangunan. Warga desa dan anak-anak sekolah terganggu aktifitasnya karena harus menyeberangi sungai yang berbahaya. Peristiwa tersebut awalnya diberitakan oleh program berita Liputan 6 SCTV yang konsen memberitakan konten berita yang bersifat sosial dan human interest.

Dalam rapat diputuskan bahwa SCTV bertekad akan membangun satu sampai tiga jembatan yang dibutuhkan oleh masyarakat. Untuk tim survei ditunjuk 
Yayasan Relawan Kampung yang sudah berpengalaman membangun jembatan dan koresponden daerah dari divisi pemberitaan SCTV untuk mengumpulkan data. Dari hasil survei diputuskan bahwa yang pertama adalah Jembatan Gantung di desa Jayasari, Kecamatan Cimarga, Kabupaten Lebak, Banten.

Menurut Doni Ariyanto, "pada pelaksanaan program jembatan asa, SCTV akan mengutamakan pendanaan dari donasi masyarakat (fundraising) untuk membiayai pembangunan jembatan dan keterlibatan warga sekitar jembatan secara aktif atau gotong royong. Sebagai bentuk CSR, SCTV akan membiayai seluruh proses pengelolaan pembangunan jembatan, mulai dari survei lokasi, transportasi, hingga pengawasan pembangunan, serta kampanye penggalangan dana secara gratis di media massa milik grup EMTEK, yaitu media televisi SCTV, Indosiar dan media online Liputan6.com. sedangkan jenis kampanye yang akan digunakan adalah iklan, publikasi berita, running text, kegiatan on air di dalam program hiburan, serta kegiatan off air. Intinya akan digunakan segala media untuk mengajak masyarakat agar mau berbagi meringankan beban sesama dengan mendonasikan sebagian hartanya pada kegiatan pembangunan jembatan. Kata "asa” sengaja dipilih untuk menggambarkan besarnya harapan masyarakat agar akses jembatan yang mereka butuhkan dapat terealisasi”.

Dalam kampanye penggalangan dana, penyelenggara menggunakan semua media yang dimiliki oleh PT. Surya Citra Televisi dan grup medianya, baik melalui media tradisional yaitu program-program di stasiun televisi SCTV maupun melalui media online liputan6.com dan media sosial.

\section{PEMBAHASAN}

Model kampanye yang digunakan untuk menganalisis penerapan kampanye penggalangan dana kegiatan kemanusiaan “jembatan asa” SCTV adalah model Nowak dan Warneryd.. Alasannya berdasarkan hasil wawancara penulis dengan Doni Arianto sebagai ketua penyelenggara kegiatan kemanusiaan, selama pelaksanaan kampanye terjadi perubahan tujuan yang dikehendaki, sehingga implementasi pelaksanaan kampanye pun berubah, mengikuti tujuan yang diinginkan penyelenggara kegiatan. Model ini juga menyarankan bagaimana bertindak sistematis dalam meningkatkan efektivitas kampanye. 
Dalam model Nowak dan Warneryd terdapat delapan elemen kampanye yang harus diperhatikan:

1. Intended effect (efek yang diharapkan). Efek yang hendak dicapai harus dirumuskan dengan jelas. Efek yang hendak dicapai dalam kampanye penggalangan dana program CSR jembatan asa adalah perubahan perilaku masyarakat (changing behaviour) agar mau mendonasikan hartanya untuk pembangunan jembatan yang dikelola oleh SCTV. Hal ini senada dengan Doni Arianto yang menyatakan bahwa "semakin banyak masyarakat yang menyumbang, maka SCTV bisa membangun lebih banyak lagi jembatan sesuai keinginan masyarakat yang membutuhkan".

Menurut Doni Arianto, ide penggalangan dana berawal banyaknya pemberitaan di media massa yang mengangkat masalah terputusnya akses transportasi di berbagai daerah akibat banyak jembatan putus yang sudah bertahun-tahun tidak diperbaiki.

Pendapat ini diperkuat Mauluddin Anwar, yang menyatakan bahwa dalam perencanaan kampanye penggalangan dana, hal yang terpenting adalah adanya "momentum" baik peristiwa musibah yang sedang terjadi atau kondisi masyarakat yang sedang banyak diberitakan media massa.

\section{Competiting}

Communication (persaingan komunikasi). Agar suatu kampanye menjadi efektif, maka perlu diperhatikan potensi gangguan dari kampanye yang bertolak belakang (counter campaign).

Dalam perencanaan kampanye Jembatan Asa, kegiatan penggalangan dana yang dilakukan media massa lain atau pun dari organisasi nirlaba, tidak menjadi salah satu tolak ukur, karena SCTV sendiri awalnya tidak mempunyai target besar terkait jumlah sumbangan masyarakat. SCTV lebih fokus pada bagaimana mengampanyekan program jembatan asa melalui media televisi dengan menyasar target audiens SCTV. Padahal saat kampanye berlangsung, hampir semua media memiliki kegiatan fundraising atau filantropi, yang dananya bersumber dari masyarakat. Misalnya : Indosiar Peduli Kasih, RCTI Peduli, dan lain-lain..

Kendala justru muncul saat kampanye sudah berlangsung, salah satunya adalah masalah birokrasi pemerintah daerah. Doni mencontohkan, rencana pembangunan 
jembatan di Kabupaten Maros, Sulawesi Selatan. Rencana pembangunan jembatan yang sudah disurvei dan disetujui warga, serta sudah dipublikasikan dan dipromosikan melalui media massa, terpaksa dibatalkan karena Bupati setempat merasa tersinggung dan akan membangun sendiri jembatan tersebut menggunakan dana APBD. Sementara banyak masyarakat sudah terlanjur menyumbang pembangunan jembatan di Kabupaten Maros tersebut. SCTV pun terpaksa harus memublikasikan pembatalan rencana pembangunan dan mengalihkan ke pembangunan jembatan di wilayah lain.

Sedangkan dari hasil focus group discussion (FGD), pemirsa juga memperhatikan bidang tujuan dari penggalangan dana tersebut. Beberapa peserta FGD lebih memilih memprioritaskan sumbangan untuk program kesehatan,, alasannya membantu orang sakit bersifat urgent atau segera, karena jika tidak diobati kemungkinan dampaknya akan berbahaya bagi pasien. Bidang lain yang menjadi prioritas sumbangan adalah pendidikan, menurut sebagian peserta, pendidikan sangat penting bagi masyarakat untuk masa depan mereka.
Sementara alasan peserta yang memilih menyumbang jembatan asa karena pembangunan infrastruktur dianggap berdampak langsung ke berbagai lapisan masyarakat, diantaranya meningkatkan ekonomi warga, mempermudah siswa sekolah dan mempermudah membawa orang sakit.

Terkait kepercayaan terhadap lembaga pengelola penggalangan dana, sebagian peserta FGD menganggap organisasi nirlaba yang fokus bergerak di bidang pengelolaan dana masyarakat seperti Dompet Dhuafa dan Aksi Cepat Tanggap (ACT) dinilai lebih terpercaya dibanding media massa. Sedangkan sebagian peserta FGD lain menganggap media massa punya reputasi, sehingga tidak mungkin menyelewengkan dana masyarakat.

3. Communications object (obyek komunikasi).

Obyek kampanye difokuskan pada ajakan kepada masyarakat untuk mendonasikan hartanya mendukung kegiatan kemanusiaan yang dikelola SCTV yaitu Pembangunan Jembatan Asa. Mauluddin Anwar menjelaskan bagaimana kampanye di media massa saling terkait untuk memberitakan kondisi masyarakat yang terdampak 
jembatan rusak, hingga progres

pembangunan jembatan.

Pemberitaan media internal

SCTV yaitu program Liputan 6

Pagi, Liputan 6 Siang dan

Liputan 6 Malam secara reguler

terus meng-update isi

pemberitaan tentang pelaksanaan

program jembatan asa, mulai

dari kondisi masyarakat yang

terdampak jembatan rusak,

peletakkan batu pertama

pembangunan jembatan, respons

masyarakat yang ikut membantu

pembangunan, progres

pembangunan tiap bulan,

peresmian jembatan hingga

masyarakat yang termudahkan

setelah akses jembatan bisa

digunakan. Publikasi ini juga

sebagai laporan

pertanggungjawaban atas

pengelolaan dana masyarakat.

\section{Target population \& receiving group} (populasi target dan kelompok penerima).

Kelompok penerima adalah bagian dari populasi target. Kelompok penerima dan populasi target dapat diklasifikasikan menurut sulit atau mudahnya mereka dijangkau oleh pesan kampanye. McQuail dan Windhal mendefinisikan khalayak sasaran sebagai sejumlah besar orang yang pengetahuan, sikap dan perilakunya akan diubah melalui kegiatan kampanye. Besarnya jumlah khalayak sasaran ini mengindikasikan bahwa mereka memiliki karakteristik yang beragam, sehingga cara mereka merespons pesan kampanye menjadi berbeda.

Pemilihan target audiens adalah memilih satu atau beberapa segmen audiens yang akan menjadi fokus kegiatan-kegiatan pemasaran program dan promosi. Pemilihan segmen audiens dilakukan berdasarkan riset yang memadai dengan pertimbanganpertimbangan yang masak. Clancy dan Shulman dalam Morrisan (2008:194) menyatakan bahwa ada empat kriteria yang harus dipenuhi oleh pengelola media penyiaran untuk mendapatkan khalayak sasaran yang optimal, yaitu 1) responsif, 2) potensi penjualan, 3) pertumbuhan memadai dan 4) jangkauan iklan.

Awalnya penyelenggara Jembatan Asa memfokuskan sasaran kahalayak pada audiens loyal SCTV, yaitu masyarakat kelas sosial A, B, dan C yang merupakan audiens program 
berita liputan 6. Pada perkembangannya populasi target yang dituju diperluas lagi kepada seluruh lapisan masyarakat, mulai kelas A hingga E. Kondisi ini membuat media kampanye penggalangan dana pun di perluas dengan memaksimalkan semua medium yang dimiliki oleh SCTV dan perusahaan grup nya. Hal ini terlihat dari hasil donasi yang disumbangkan masyarakat yaitu dari kelas sosial terendah yaitu kelas $\mathrm{E}$ dengan nilai donasi mulai Rp. 10.000 sampai kelas sosial tertinggi yaitu kelas A, yang mampu menyumbang hingga Rp. 100 juta rupiah.

Dalam wawancara, Doni Arianto menyatakan bahwa jumlah masyarakat penyumbang terbesar justru dilakukan oleh masyarakat kelas C-E, dengan nilai sumbangan antara Rp. 10.000 hingga Rp.100.000. Hal ini terlihat dari total penyumbang yang mencapai lebih dari 19 ribu orang. Sedangkan jumlah masyarakat kelas A dan B dengan nilai sumbangan diatas Rp. 1 juta tidak terlalu banyak. Walau pun ada individu yang menyumbang hingga Rp. 100 juta.

Adanya perubahan khalayak sasaran penyumbang membuat pengelola memperluas medium siaran, kampanye tidak hanya dilakukan pada audiens SCTV yang mayoritas khalayak sasaran kelas C,D,E, namun memperluas kepada masyarakat kelas A dan B serta warganet pengguna media sosial.

\section{The channel (saluran).}

Saluran kampanye jembatan asa yang digunakan oleh SCTV terbagi menjadi 2, yaitu melalui media tradisional dalam penayangan program di SCTV dan melalui new media.

a. Media tradisional, kampanye penggalangan dana dilakukan melalui program-program yang ditayangkan oleh SCTV sendiri antara lain: Program Berita Liputan 6, Program Infotainment Halo Selebritis dan Was-was, serta Program Hiburan Inbox.

b. New media dibagi menjadi dua yaitu media online dan media sosial.

\section{Media Online (online media)}

Online media merupakan media yang dapat di akses kapan saja selama ada jaringan internet. Unsur inilah yang membedakan dengan media konvensional, karena itu media online tidak dikategorikan ke dalam media cetak maupun media elektronik, 
melainkan sebagai media massa baru (New Media) atau media modern (Suryati, 2011:113-114). Untuk memperluas khalayak sasaran (target audience), kampanye penggalangan dana program jembatan asa menggunakan media online yang dimiliki grup SCTV yaitu website berita online www.liputan6.com dan website resmi perusahaan www.sctv.co.id.

\section{Media Sosial}

Media sosial adalah sebuah media yang para penggunanya bisa dengan mudah berpartisipasi, berbagi, dan menciptakan isi, meliputi blog, jejaring sosial, wiki, forum dan dunia virtual. Blog, jejaring sosial dan wiki merupakan bentuk media sosial yang paling umum digunakan oleh masyarakat di seluruh dunia. Jejaring sosial merupakan sebuah sistem struktur sosial yang terdiri dari elemenelemen individu atau organisasi. Jejaring sosial ini akan membuat mereka yang memiliki kesamaan sosialitas, mulai dari mereka yang telah dikenal sehari-hari sampai dengan keluarga bisa saling berhubungan.

Pemanfaatan situs jejaring sosial atau Social Networking sudah menjadi tren atau gaya hidup bagi sebagian besar masyarakat. Terdapat dua situs jejaring sosial yang paling terkenal dan banyak digunakan oleh masyarakat di Indonesia adalah facebook dan twitter.

a. Facebook

Publikasi melalui media sosial facebook dilakukan SCTV melalui akun yang bisa dibuka dalam link :

https://www.facebook.com/S urya.Citra.TV. Melalui media sosial facebook, admin SCTV rutin meng-update status berisi publikasi perkembangan informasi pengelolaan program jembatan asa. Informasinya berisi jumlah nominal hasil donasi masyarakat dan berita perkembangan pembangunan jembatan asa yang mulai berjalan.

b. Twitter 


\begin{abstract}
Memahami besarnya respon masyarakat pengguna twitter, maka kampanye penggalangan dana juga dilakukan melalui media twitter dengan akun @SCTV_ yang dikelola oleh profesional karyawan SCTV. Selama kampanya, admin twitter SCTV biasanya menggunakan hashtag berupa

\#JembatanAsaSCTV.

Hashtag biasanya digunakan oleh kelompok atau organisasi untuk topik tertentu, dan biasanya menjadi berita yang sedang hangat dibicarakan (trending topic). Hashtag yang diberi simbol tanda pagar (\#) digunakan untuk mempermudah penggunanya dalam mencari topik yang dibicarakan (Poynter, 2010:300).
\end{abstract}

Twitter yang didirikan oleh Jack Dorsey pada Maret 2006, memberikan kemudahan kepada orang-orang untuk mengetahui dan memperdalam hubungan antar manusia, juga mempermudah dalam promosi produk.

6. The message (pesan).

Pesan untuk mengajak masyarakat menyumbang dalam penggalangan dana program jembatan asa dilakukan dalam bentuk iklan dan berita. Iklan penggalangan dana berisi informasi cara berdonasi yaitu melalui rekening Bank BCA Rek. 500519 2525, BCA Cabang Senayang City Jakarta.

Sedangkan ajakan berdonasi dilakukan melalui isi pemberitaan human interest di program Liputan 6 SCTV. Pesan dapat dibentuk sesuai dengan karakteristik kelompok yang menerimanya. Pesan juga dapat dibagi menjadi tiga fungsi yaitu: menumbuhkan kesadaran, mempengaruhi, serta memperteguh dan meyakinkan penerima bahwa pilihan atau tindakan mereka adalah benar. Penataan agenda (agenda Setting) mengacu kepada kemampuan media massa untuk mengarahkan perhatian khalayak terhadap isu-isu tertentu yang diagendakan media massa. Media massa dapat mempengaruhi khalayak tentang apa yang ada dalam pikiran mereka. Artinya media massa mempengaruhi 
persepsi khalayak mengenai apa yang dianggap penting. Dalam penerapannya, media massa membuat agenda tertentu mengenai apa yang harus dipikirkan oleh khalayak dengan memilih dan mengemas informasi yang dikehendaki. Setelah itu khalayak membentuk persepsinya berdasarkan informasi yang diterimanya dari media massa.

Menurut Mauluddin Anwar, Kepala Divisi Produksi Berita SCTV, dari awal ide pelaksanaan program jembatan asa justru karena maraknya pemberitaan kondisi kemiskinan masyarakat daerah terpencil yang belum tersentuh pembangunan. Perjuangan anak-anak SD yang harus menantang maut menyeberang jembatan rusak, memunculkan empati dan simpati masyarakat untuk ikut berbagi meringankan beban mereka. Salah satu contoh adalah jembatan di desa Jayasari, Kecamatan Cimarga, Kabupaten Lebak, Banten, yang kemudian menjadi proyek pertama pembangunan jembatan asa. Kondisi masyarakat yang memprihatinkan diliput oleh koresponden SCTV ternyata memiliki share yang tinggi dan mendapat respons dari masyarakat.

Lita Haryani, Manajer Produksi
Berita SCTV menambahkan bahwa dalam praktiknya, agenda setting berita jembatan asa memang diarahkan lebih "drama", sesuai karakter khalayak SCTV yang menyukai sinetron. Jadi ketika sisi human interest ditonjolkan, masyarakatt seolah tersadar bahwa masih banyak saudara-saudara kita yang kekurangan dan membutuhkan uluran tangan orang lain. Di sini kita meminta para produser agar membuat berita yang "menyentuh hati" dengan memadukan naskah yang naratif dan gambar-gambar tentang "perjuangan" masyarakat desa untuk melewati jembatan. Narasumber berita sengaja dipilih para petani yang kesulitan menjual hasil bumi karena tidak ada jembatan dan siswa SD yang harus menantang maut untuk menuntut ilmu.

7. The communicator / sender (komunikator / pengirim pesan). Komunikator dapat dipilih berdasarkan pertimbangan tertentu, misalnya seorang ahli atau seseorang yang dipercaya khalayak atau malah seseorang yang memiliki kedua sifat tersebut. Komunikator harus memiliki kredibilitas yang tinggi dimata penerima pesannya.

Dalam kampanye ini, SCTV tidak menggunakan komunikator khusus 
untuk mengajak masyarakat berdonasi.

Akan teetapi sebagai perusahaan media massa, SCTV memanfaatkan karyawannya atau artis yang menjadi talent dalam program-programnya sebagai endorser yang mengajak masyarakat untuk berdonasi. Dalam Program berita Liputan 6, presenter diakhir program mengajak masyarakat untuk menyumbang program jembatan asa. Untuk Program infotainmen, artis terkenal Prilly Latuconsina ikut mendatangi lokasi jembatan dan menjadi narasumber.

8. The obtained effect (efek yang dicapai). Efek kampanye meliputi efek kognitif (perhatian, peningkatan pengetahuan dan kesadaran), afektif (berhubungan dengan perasaan, mood dan sikap), dan konatif (keputusan bertindak dan penerapan). (Venus 2004:22-24).

Efek yang ingin dicapai dalam kampanye penggalangan dana program jembatan asa adalah adanya kesadaran masyarakat untuk menyumbangkan sebagian hartanya melalui rekening yang dikelola SCTV.

Dari target awal penyelenggara hanya akan mengumpulkan dana untuk membangun 1satu hingga tiga jembatan, ternyata hasil donasi masyarakat yang terkumpul mencapai
Rp 4.546.241.368,-, sehingga bisa digunakan untuk membangun sepuluh Jembatan Asa.

Selain itu, kampanye masif melalui berbagai saluran informasi, juga menjadi kritik sosial bagi pemerintah daerah untuk segera memperbaiki infrastruktur jembatan yang rusak di daerahnya. Hal ini dikemukakan Doni Arianto, yang menyatakan bahwa beberapa kepala daerah justru menolak izin perbaikan jembatan dari SCTV, namun memasukkan perbaikan jembatan ke dalam APBD tahun berikutnya. Seperti yang dilakukan bupati kabupaten Maros, Sulawesi Selatan.

\section{Model Kampanye Penggalangan Dana di} Media Televisi

Mengacu pada model kampanye Nowak dan Warneryd, peneliti menemukan perubahan model yang digunakan SCTV dalam kampanye penggalangan dana masyarakat.

Pertama, adanya peristiwa atau momentum yang terjadi. Dalam kampanye diatas, momentumnya adalah maraknya jembatan rusak di berbagai daerah terpencil, yang memutus akses transportasi masyarakat. Kondisi tersebut kemudian dipublikasikan secara masif oleh SCTV. 
Jadi sebelum kampanye dilakukan, SCTV sudah memproduksi framing berita tentang masyarakat yang terdampak jembatan rusak, demi kepentingan news room.

Kedua, efek yang diharapkan muncul setelah masif nya pemberitaan suatu peristiwa (bencana, kemiskinan, dll) adalah adanya kepedulian masyarakat untuk membantu para korban dengan cara menyumbang sebagian hartanya.

Ketiga, kendati hampir tiap media massa memiliki program penggalangan dana secara reguler, namun ternyata kompetisi dari media sejenis tidak menjadi tolak ukur dalam menyusun kampanye. Salah satu alasannya adalah program jembatan asa memiliki diferensiasi (pembeda) dengan program fundraising lain, yaitu hanya fokus pada pembangunan infrastruktur jembatan di daerah terpencil, yang sebelumnya sudah disurvei. Obyek kampanye penggalangan dana terdiri dari promosi ajakan berdonasi baik melalui iklan maupun cross promo program, berita terkini progres pelaksanaan kegiatan pembangunan jembatan, serta running text dan laman website yang berisi laporan keuangan masyarakat yang terkumpul. Dalam kampanye, SCTV tidak menggunakan komunikator khusus, tetapi menyerahkan pada presenter berita atau talent program hiburan untuk meng- endorse penonton agar ikut berdonasi.

Keempat, sasaran audiens disesuaikan dengan saluran yang digunakan. Untuk audiens SCTV, kampanye dilakukan melalui tayangan pada beberapa program seperti news, infotainment maupun hiburan. Sedangkan sasaran warganet atau pengguna media sosial yang saat ini marak, SCTV memublikasikan ulang melalui media sosial twitter, facebook, website www.sctv.co.id dan menggandeng media lain dalam satu grup, yaitu media online liputan6.com.

Kelima, hasil kampanye yang didapat melebihi target yang dicanangkan, dari rencana membangun hanya tiga jembatan, ternyata donasi yang terkumpul bisa digunakan untuk membangun sepuluh jembatan. Selain itu, kampanye yang masif juga membuat beberapa pemerintah daerah tergerak untuk memperbaiki infrastruktur jembatan di wilayahnya yang rusak dengan memasukkan pada rencana APBD tahun berikutnya.

Dari delapan elemen pada model kampanye Nowak dan Warneryd, SCTV mengabaikan elemen persaingan komunikasi (competiting commuication), penggunaan opinion leader pada kelompok penerima (receiving group) dan penggunaan komunikator khusus untuk berkampanye. 
Dari adaptasi kampanye diatas, model

kampanye penggalangan dana oleh media

televisi, bisa dibuat sebagai berikut.

\section{MODEL KOMUNIKASI KAMPANYE PENGGALANGAN DANA DI TELEVISI}

\section{Titik Tolak}

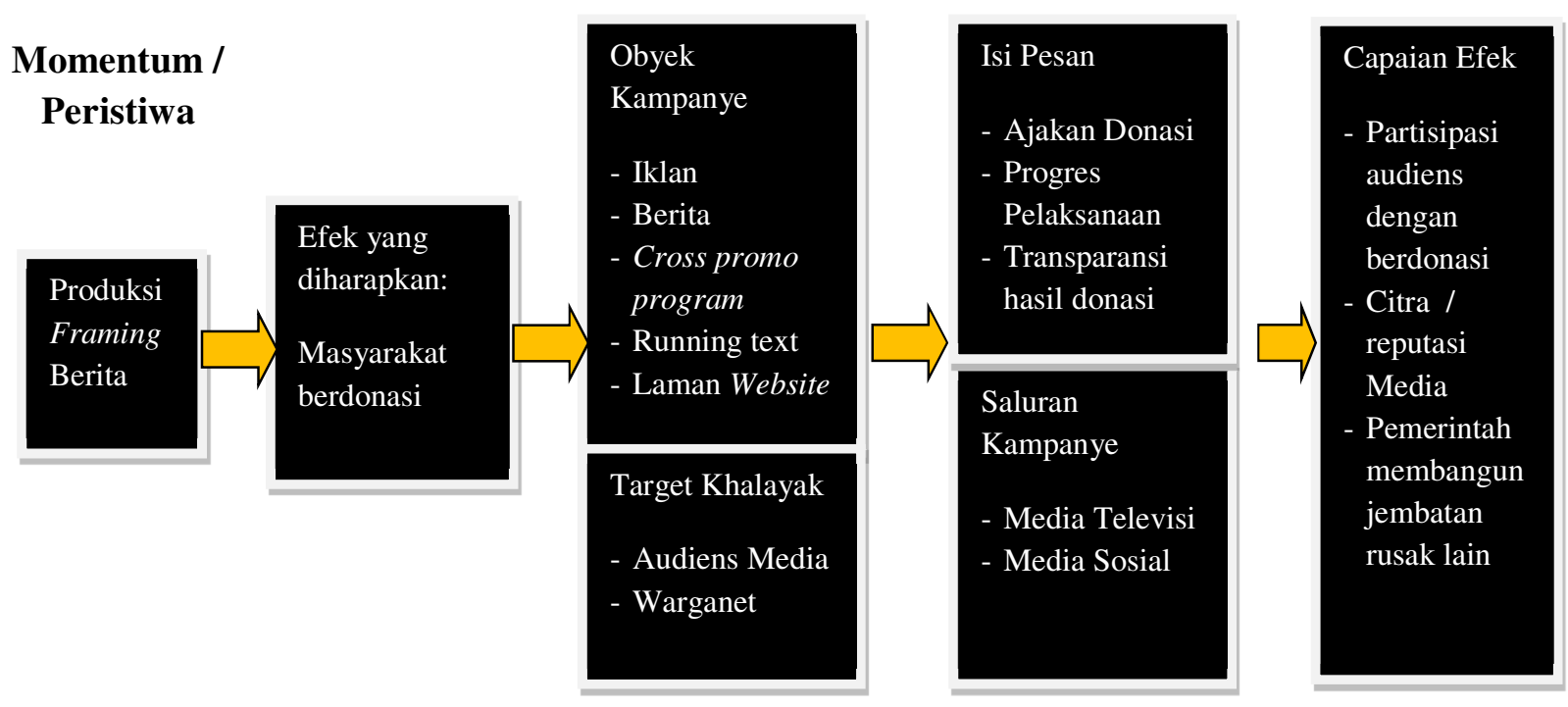




\section{SIMPULAN}

1. Media kampanye menggunakan media tradisional yaitu kampanye dalam program berita Liputan 6, program infotainmen Was-was dan Halo Selebriti, serta program hiburan Inbox yang semuanya tayang di SCTV. Sedangkan kampanye melalui new media, dilakukan dengan cara publikasi di media online, www.liputan6.com dan www.sctv.co.id. Sedangkan publikasi media sosial dilakukan melalui facebook https://www.facebook.com/Surya.Citra $\underline{. T V}$ dan twitter @ SCTV.

2. Mengacu pada elemen model kampanye Nowak dan Warneryd; efek yang diharapkan, persaingan komunikasi, obyek komunikasi, populasi target dan kelompok penerima, saluran, pesan, komunikator, dan efek yang dicapai. Peneliti menemukan perubahan model yang digunakan SCTV dalam kampanye penggalangan dana masyarakat. Diantaranya, sebelum melakukan kampanye, SCTV memproduksi framing berita kondisi masyarakat terdampak jembatan rusak. Isi pesan kampanye berupa iklan ajakan berdonasi, pemberitaan progres pembangunan jembatan dan laporan keuangan. Efek kampanye yang dicapai adalah banyaknya donasi masyarakat, naiknya reputasi media, dan kepedulian pemerintah untuk membangun jembatan rusak lain di wilayahnya. Sementara elemen persaingan komunikasi (competiting commuication), penggunaan opinion leader pada kelompok penerima (receiving group) dan penggunaan komunikator khusus untuk berkampanye, diabaikan oleh SCTV.

\section{SARAN}

1. Penerapan kampanye penggalangan dana program jembatan asa yang dilakukan SCTV dengan mengoptimalkan seluruh media yang dimiliki, sangat efektif mencapai khalayak luas, jika tidak memperhitungkan biaya pemasangan iklan dan publikasi di media massa. Penerapan kampanye seperti ini tidak efektif digunakan, jika pengelola fundraising adalah organisasi non media.

2. Kampanye yang menyasar pada masyarakat lebih susah diprediksi hasilnya, karena sangat mungkin akan mengalami kejenuhan pada kegiatan lanjutan sejenis. Apalagi jika ada kegiatan kemanusiaan lain yang lebih "menyentuh" masyarakat. SCTV perlu 
mengembangkan khalayak dengan mengajak perusahaan agar mau membagikan dana CSR-nya bagi kegiatan kemanusiaan. Tentunya kampanye dengan sasaran perusahaan membutuhkan strategi kampanye yang berbeda.

\section{UCAPAN TERIMA KASIH}

Penulis mengucapkan terima kasih sebesar-besarnya kepada manajemen PT Surya Citra Televisi (SCTV) yang telah memperkenankan dilakukan penelitian ini, terlebih kepada para narasumber (key informan) di SCTV yaitu: Doni Arianto, manajer programming dan ketua pelaksana penggalangan dana program Jembatan Asa, Mauluddin Anwar (Kepala Produksi Berita), Lita Hariyani (Manajer Pemberitaan), Kurnia Supriyatna (Video Journalist). Juga kepada para peserta focus group discussion (FGD) yang tidak bisa disebutkan satu per satu.

Ucapan terima kasih tak terhingga juga diberikan kepada Direktorat Riset dan Pengabdian Masyarakat, Direktorat Jenderal Penguatan Riset dan Pengembangan, Kementerian Riset, Teknologi dan Pendidikan Tinggi, sesuai dengan kontrak penelitian Nomor: 0411/K3/KM/2017, yang telah membiaya penelitian ini secara penuh.

\section{DAFTAR PUSTAKA}

Bungin, Burhan. 2007.Penelitian Kualitatif Komunikasi, Ekonomi, Kebijakan Publik, dan Ilmu Sosial Lainnya.
Jakarta: Kencana Prenada Media Group.

Gregory, A. 2004. Perencanaan dan Manajemen Kampanye Public Relations (Edisi Kedua). Jakarta: Penerbit Erlangga.

Kriyantono, Rachmat. 2012. PR Writing: Teknik Produksi Media Public Relations dan Publisitas Korporat. Jakarta: Kencana.

McNabb, David. 2002. Research Methods in Public Administration \& Nonprofit Management: Quantitative \& Qualitative Approaches. M.E. Sharpe.

Moleong, Lexy. 2001. Metodologi Penelitian Kualitatif. Bandung: PT Remaja Rosdakarya.

Morrisan, 2008. Strategi Menjadi Humas Profesional. Jakarta:Kencana

Purwanto, April.2009. Manajemen Fundraising Bagi Organisasi Pengelola Zakat, Jakarta:Teras

Ruslan, Rosady. 1998. Manajemen Public Relations \& Media Komunikasi Konsepsi dan Aplikasi. Jakarta: Raja Grafindo Persada.

Soemirat, Soleh \&Ardianto, Elvinaro, 2007, Dasar-Dasar Public Relations, Bandung, Rosdakarya

Sudewo, Eri. 2004. Manajemen Zakat. Ciputat: Institut Manajemen Zakat. Sugiyono. 2012. Metode Penelitian Kuantitatif Kualitatif dan $R \& B$ Bandung: Alfabeta.

Suryawati, Indah. 2011. Jurnalistik Suatu Pengantar: Teori dan Praktek. Bogor: Ghalia Indonesia

Venus, Antar. 2004. Manajemen Kampanye - Panduan Teoretis dan Praktis dalam 
Mengefektifkan Kampanye

Komunikasi. Bandung: Simbiosa Rekatama Media.

Website: www.liputan6.com

www.sctv.co.id 